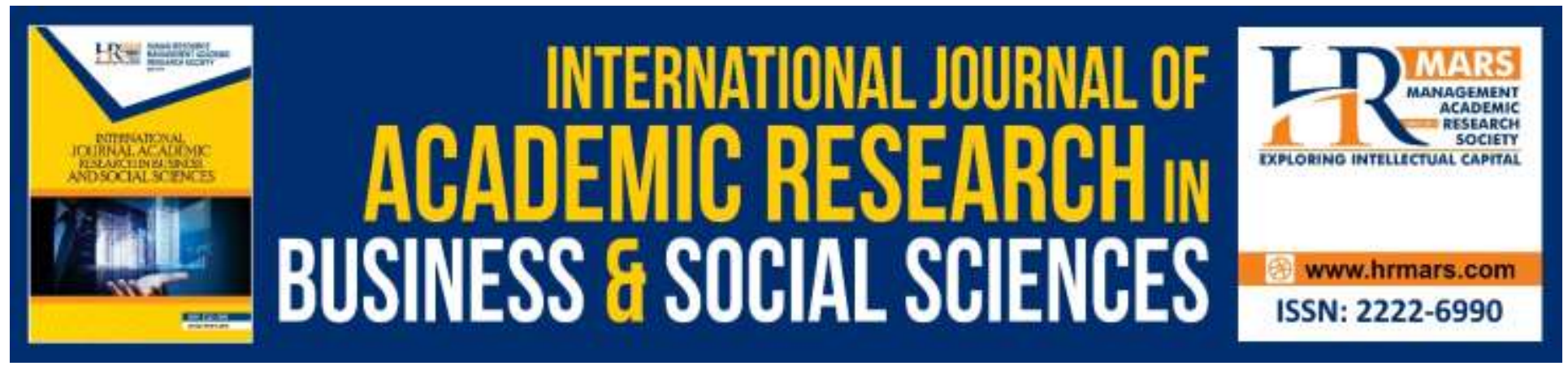

\title{
The Healer of all Diseases in Al-Quran: A Review
}

\author{
Wan Nur Sabrina Binti Wan Mohd Yusuff, Wan Khairul Aiman Wan Mokhtar, \\ Eusoff Amiruddin, Rosmalizawati Abd. Rashid, Mohd Faiz Hakimi Mat Idris \& \\ Ahmad Zahid Salleh
}

To Link this Article: http://dx.doi.org/10.6007/IJARBSS/v9-i11/6576

DOI: 10.6007/IJARBSS/v9-i11/6576

Received: 10 October 2019, Revised: 30 October 2019, Accepted: 03 November 2019

Published Online: 13 November 2019

In-Text Citation: (Yusuff et al, 2019)

To Cite this Article: Yusuff, W. N. S. B. W. M., Mokhtar, W. K. A. W., Amiruddin, E., Rashid, R. A., Idris, M. F. A. W., \& Salleh, A. Z. (2019). The Healer of all Diseases in al-Quran: A Review. International Journal of Academic Research in Business and Social Sciences, 9(11), 565-571.

Copyright: (C) 2019 The Author(s)

Published by Human Resource Management Academic Research Society (www.hrmars.com)

This article is published under the Creative Commons Attribution (CC BY 4.0) license. Anyone may reproduce, distribute, translate and create derivative works of this article (for both commercial and non-commercial purposes), subject to full attribution to the original publication and authors. The full terms of this license may be seen at: http://creativecommons.org/licences/by/4.0/legalcode

\section{Vol. 9, No. 11, 2019, Pg. 565 - 571}

Full Terms \& Conditions of access and use can be found at http://hrmars.com/index.php/pages/detail/publication-ethics 


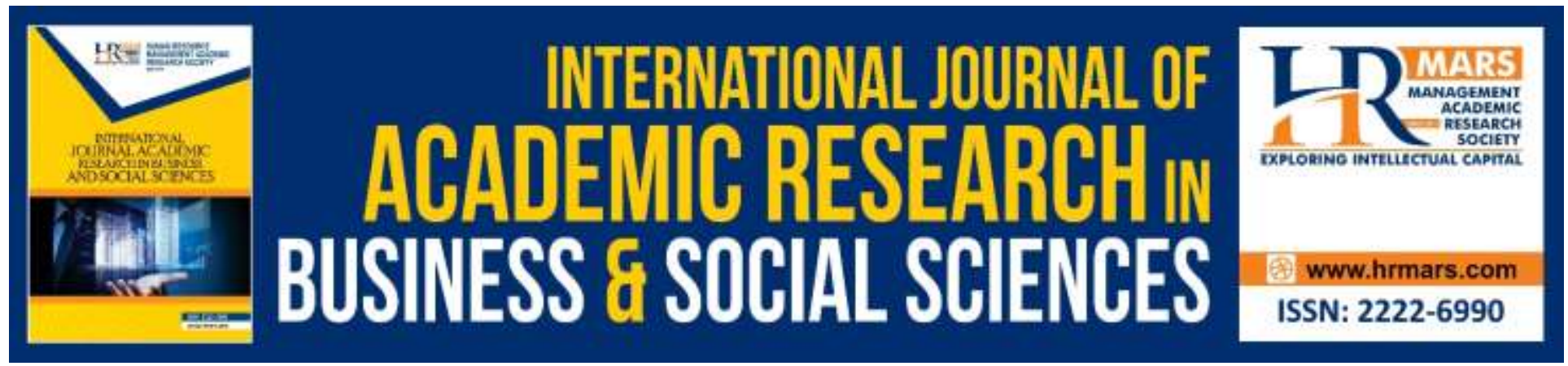

\title{
The Healer of all Diseases in Al-Quran: A Review
}

\author{
Wan Nur Sabrina Binti Wan Mohd Yusuff, Wan Khairul Aiman \\ Wan Mokhtar, Eusoff Amiruddin, Rosmalizawati Abd. Rashid, \\ Mohd Faiz Hakimi Mat Idris \& Ahmad Zahid Salleh
}

Universiti Sultan Zainal Abidin (UniSZA), Kampus Gong Badak, 21300, Kuala Nerus, Terengganu, Malaysia

\begin{abstract}
This article reports a study of the evidence verse of the Quran can cure the disease either physically or spiritually. All people living in the world have suffered from either mild or severe disease. Every disease has a cure for the disease. Normally, physical ailments treated by doctors who are experts in their field. Meanwhile, the spiritual diseases such as harassment and magic genie need people who are experts in the field of Islamic medicine. However, both types of diseases can be cured by using Quran verses. Practice methods of treating diseases by reading Quran verses has become a habit for Muslims in Malaysia in particular. This practice requires a strong spirit and confidence of nurses to patients treated confident and hopes wholly to Allah. Indeed, the illness will be cured with a business and trust and with His permission. Illness suffered by a person is actually a test of Allah so that they remember and turn to Allah. What evidence exists to suggest that the Quran verses can cure disease? How do the Quran verses can cure all types of diseases? In answering this questions, there are objective in this article, namely the first, to analyse and identify evidence to suggest that the disease can be cured not only with a doctor's treatment methods or drugs but also can be cured with the use of the Quran verses. This qualitative study using the library, World Wide Web, article, journal and the data were analysed by the method of document analysis. The findings contained in this article are reviewing and examining that selective evidence in the Quran verses can cure diseases.
\end{abstract}

Keywords: Diseases, Quran verses, Evidence, Cure

\section{Introduction}

As we know, all diseases, especially chronic diseases such as hypertension, heart disease, diabetes and others can be cured by a doctor, take medication and so on. Apart from modern treatments, there are advantages and miracles in the Quran also can cure these diseases. This is because the power of the healer is Allah's entirely and without the permission of His, disease that person have cannot be cured. Indeed, there is not a disease of the liver and the body unless there 
is in the Quran arguments that demonstrate the drug and reasons. Evidence of the Quran can cure disease through the word of Allah says: And We send down from the verses of the Quran something that can be syifa '(cure) and a mercy to those who believe. (Surah Al-Isra: 82).

There are questions in this article which; what evidence exists to suggest that the Quran verses can cure disease? How do the Quran verses can cure all types of diseases? These are the factors that led to this study need to be done.

The discussion of the evidence and the method of how the Quran can cure all diseases on earth is important to realize man that the Quran has a lot of miracles that can be derived from it. Therefore, in answering the question, methods literature and data were analysed with document analysis method used in this research. There are two objectives in this article, namely, reviewing the selected Quran verse that can be proved as a cure of disease and examining how the Quran verse cure the disease even the physical disease.

Overall, the discussion in this article is about the evidence Quran can cure illness whether physical or spiritual. This shows that the Qur'an has many miraculous and its inherent advantages. In addition, this study also proves that Islam was very beautiful and holy book Quran brings many blessings to all mankind.

\section{Research Methodology}

To achieve the objectives of this study, the method used is by using qualitative methods. The methods used in this research are literature and library methods, World Wide Web, article, journal and data analysed with document analysis method. Collecting data about this article review was prepared by the following procedures (Mokhtar, 2017; Ramasamy, Rahman, Manaf, \& Said, 2018).

\section{Findings and Research Discussion}

In the discussion of this article, there are some scopes of the verses of the Quran were discussed. Among them are the evidences that verses of the Quran can cure the disease, the purpose and benefits of the medication Quran and how disease can be cured by reading verses of the Quran.

\section{The Evidences That Verse of the Quran Can Cure the Disease}

There are some words syifa' which proves that the Quran is the source of medicine for all diseases. Evidence of the Quran can cure disease through the Word of God says one of them is: "And We send down from the verses of the Quran something that can be syifa' (cure) and a mercy to those who believe and the Quran did not increase loss than those who do wrong." (Surah AlIsra: 82) This verse shows that the Quran was revealed to be as a remedy in all diseases. Through the study of this article, the researcher informed that the Quran is a healing remedy that can eliminate diseases such as heart disease or even spiritually and physically. In addition, the Quran also serves as a blessing that brings wisdom so that humanity can find goodness despite the miracles contained in the Quran. The researcher wrote the article about Allah's Word again: "O mankind, indeed has come to you from your Lord and a healing for the diseases (that are) in the 
chest and guidance and mercy for people who believe." (Surah Yunus: 57) and "Say, Al-Quran is a guide and antidote for those who believe." (Surah Fussilat: 44) (Kamus, 2016).

Moreover, the Quran is medication and also healing for the physical and spiritual illnesses such as mental illness or disorder spirits and magic. The verses of syifa' contained in the Quran is also important apart from modern medicine as medical treatment or medication. The method through revelations and miracles would be amazing to be felt with the help and permission of Allah. All diseases that are sure there is no cure for the disease and that Allah also healed. This can be attributed to the word of Allah means: "and when I am ill, it is He Who heals me." If Allah wills nothing is impossible for Allah, even if the illness is severe for one but Allah can heal easily. (Surah Asy Syu'araa: 80) And to Allah prostrates whatever is in the heavens and all the creatures that crawl on the earth and (also) the whether moving while they (the angels) are not proud. They fear their Lord above them and do what they're told (them). (Surah an Nahl: 49-50) There is an order or the spirit contained in this verse and include: all creatures on earth and in the heavens like the moon, the stars, plants, animals, viruses, germs and bacteria, all bow down and submit to Allah. They all are not proud against Allah, and fear and obey Allah's plenipotentiary in all regions of the heavens and the earth. They always carry out what, Allah commanded them. Therefore, if a person has the disease, should pray and ask Allah earnestly that Allah hears and can recover from the illness. (Fadhil, 2015).

There are several examples of surah and verse cures for certain diseases. Among of them are Surah Qaaf: 16-45, Surah Ah-Qaaf: 21-28 and Surah Sod: 34-61 often for diseases that are associated with bone such as joint pain, bone fractures or spinal pain, Surah Al-Buruj: 1-22 often read to cure ailments related to stomach such as gastritis or disease associated with colon or small intestine, Surah Al-Israa ': 40-55 for patients suffering from heart disease, clogged blood vessels and heart cavities, Surah Al- Anfal to hospital infection / virus and also serves as antibiotic drugs, Surah An-Nahl to give strength or energy to the patient. Strength both physically and in terms of the strength of the internal or spiritual. Surah Al-Anbiya ', Al-Qasas, Surah Al-Ma'idah, An-Naml specific to diabetes, high blood pressure, stroke and others (Joslee, n.d.).

\section{The Purpose and Benefits of the Medication Quran}

Among the objectives and benefits of the Quran Medication that can be drawn from this author is to provide a solution according to Islam to those who suffer from the problems of life, such as illness or disease due Magic Naturally in order to avoid and escape from the snare of the devil. Second is invite people who do not know the cause of Shariah among our brothers and sisters in order to resolve the problem responsibly by returning to the Quran that can protect a person from negative things. Lastly, solve the problem by not create new problems in the form of persecution that befell the form of slander and syubhah lust, slander, offense and misguidance, evil slander and Bid'ah, slander, injustice and ignorance that cause damage to Knowledge, insights, knowledge and confidence to Allah. Imam Ibn al-Qayyim al-Jawzi (may Allah have mercy on him) said, Imam Ibn al-Qayyim al-Jawzi (may Allah have mercy on him) said, "The Quran is the most perfect remedy for all diseases of body and soul, as well as the ills of the world and the hereafter. But not everyone is eligible for the guidance of Allah to do the healing with the Quran 
INTERNATIONAL JOURNAL OF ACADEMIC RESEARCH IN BUSINESS AND SOCIAL SCIENCES

Vol. 9, No. 11, November, 2019, E-ISSN: 2222-6990 @ 2019 HRMARS

but if people are ill-treating his illness with the Quran with faith and sincerity, surrender and complete trust in Allah, and fulfil all the others would not never be able to beat the disease" (Kamus, 2016).

\section{How Disease Can Be Cured by Reading Verses of the Quran}

During the life of this world as a baby, so close your eyes, diseases lurk life every time. No one who has never suffered from either mild or severe disease. The disease commonly experienced by everyone, including fever, headache, cough and colds. Indeed, the disease is a test from Allah for us to return to Him. One way to cure the disease by reading verses of the Quran through. If one reads the Quran, reading Quran verses sound waves can make a person's heart becomes quiet when hearing it. This is because the positive wave in verses will change the negative aura that exists in a person. Quran to be as wild and protector of Muslims from bad things like magic and jinns. Thus, if someone reads the Quran, the matter will be avoided. (Rasyid, 2015)

The Imam Malik, Ibn Shihab, Urwah bin Zubair, Aisha said: When the Messenger of Allah complaining of pain, he read to him by Al-Falaq and An-Naas and blow (on the sore spot). Surah Al-Fatihah proven that this chapter can cure various diseases in an extraordinary and this chapter is the mother of the Quran surah Al-Fatihah as a chapter that has many virtues, especially in terms of medical practice Islam. Surah Al-Fatihah was read by one of the companions of the Prophet to treat a villager who was stung by venomous animals. This proves that the Quran can cure the disease with high confidence and initiative person. Al-Quran and medicine have become synonymous and inseparable. The Prophet Muhammad: "to seek treatment with two drugs, namely the Quran and honey." According to the story of the companions of Abu Sa'id Al-Khudri who managed to treat people bitten by scorpions with surah Al-Fatihah as reading ruqyah. There is also a nearly paralyzed cannot walk, then recover with the permission of Allah when treated with the recitation of verses from the Quran (Bahraen, 2017).

Verses of the Quran which is a healing physical ailments can be proved by the words of Allah: "Verily, there has come to you from your Lord and a healing for the diseases (that are) in the chest and guidance and mercy for people who believe." (Surah Yunus, verse 57) Every disease has a verse of the Quran that custom. For example, prayer hypertension and diabetes occurs in Surah Yunus verse 57 and Surah Fussilat verse 44 of Surah Al-Baqarah verses 1-5 and verse of Surah Al-Mu'minun 113-118 for skin disease or allergy.

Among the methods of Islamic medicine using Quran verses is praying to Allah and zikir. One of the prayers can be read is like what was written before. Quran which has the purpose related to drug cures can be used as a prayer to cure the illness. Quran also serves as a fiber to medications. Air recited Quranic verses can be a healer to the patient when the patient is drinking the water. This is because the Quran that can be absorbed into the body and soul of the patient and will indirectly reduce the distress that was in his body (Joslee, n.d.).

Spiritual disease can also be cured by reading the verse of the Quran and this method is the most effective and common way to spiritual diseases caused by demons, devils and demons and witchcraft and relaxation. Among the sentences that can be used as a cure for the spiritual disease is Surah Al-Baqarah, Surah Ash-Syuaraa', Surah Muhammad, and more. (Joslee, n.d.) The 
use of the Quran as ruqyah or medicine began since the decline of al-Quran. Prophet Muhammad and his companions have used some verses of the Quran were elected to serve as a cure for various diseases. Among the ways that the Prophet never do is to rub in the wound site while reading certain verses of the Quran.

Some may ask, and wondered whether only the sentences were read on a person can cure the illness. To compare with existing medical nowadays are indeed contradictory because current medical need special treatment like taking medication, surgery and therapy. However, for those who have faith, sincerity and extensive knowledge about religion, healing therapy through reading the verses of the Quran to cure diseases, especially diseases spiritual and physical. (Mdekmal, 2018)

Every atom and particle in the universe is vibrating at a certain speed, a good part of the iron atom, water, and other objects. It is a scientific fact that we do not doubt. Similarly, every cell of our body vibrates in a complex system, compatible, and amazing. Vibration system of our body does not stand alone, but affected by any vibration around him. Disease is a negative foreign vibration that damage our cells vibration system (al-Kaheel, 2012; Colombos, 2018; Samail, Zaidi, Mohamed, Kamaruzaman, 2018).

\section{Conclusion}

Generally, the contents of the book of the great Qur'an al-Karim apparently has treasures of knowledge and guidance that we can do and use for various purposes such as for medical purposes benefit spiritually and physically for our mutual benefit. Referring to the discussion, only some of the verses of the Quran are used as ruqyah in the treatment of a disease. In fact, sometimes just a paragraph or a sentence. Possible sentences are combined with other prayers or other texts as an adjunct in the treatment. In this case, there is no issue of a disease that depends on the type of ruqyah, but the possible combinations and combination with some other prayer. Although the disease has a significant explicit implicit or explicit, referring to the study, the researcher can state that it is solely dependent on the knowledge gained by a nurse or practitioner in the use of a paragraph or a combination of certain verses as ruqyah.

\section{Acknowledgement}

This paper is founded on the research project of the Fundamental Research Grant Scheme FRGS/1/2018/SSI03/UNISZA/02/2 (Project No: RR279). Special appreciation is owed to Ministry of Higher Education Malaysia (MOHE) and Universiti Sultan Zainal Abidin (UniSZA) for sponsoring and supporting this research.

\section{Corresponding Author}

Wan Khairul Aiman bin Wan Mokhtar (Ph.D), Senior Lecturer, Universiti Sultan Zainal Abidin (UniSZA), Kampus Gong Badak, 21300 Kuala Nerus.

Email: wk_aiman@yahoo.com / wkhairulaiman@unisza.edu.my 
INTERNATIONAL JOURNAL OF ACADEMIC RESEARCH IN BUSINESS AND SOCIAL SCIENCES

Vol. 9, No. 11, November, 2019, E-ISSN: 2222-6990 ¿ 2019 HRMARS

\section{References}

Ahmad, K. \& Ariffin, M. F. M. (2014). Terapi Ruqyah Berasaskan Al-Quran: Analisis Signifikannya Dalam Rawatan Penyakit. The 4th Annual International Qur'anic Conference 2014 (MUQADDAS IV).

al-Kahee, A. D. (2012). Lantunan Qur'an untuk Penyembuhan. Indonesia: LKiS.

As-Suyuti, J \& Salim, M.I. (2015). Al-Quran Sang Penyembuh. Indonesia: Diandra Primamitra.

Bahraen, R. (2017). Al-Quran Obat Fisik dan Jiwa. Retrieved from muslim.or.id: https://muslim.or.id/30346-al-quran-obat-fisik-dan-jiwa.html

Colombos, A. (2018). Teaching a Second or a Foreign Language to Middle School Students with ADHD: Modern Greek Taught as in the USA as an Example. Multilingual Academic Journal of Education and Social Sciences, 6(1), 41-51

Haron, Z. (2016). Konsep Al-Shifä' dalam Al-Qur'an: Kajian terhadap metode rawatan Ibn Qayyim Al-jawziyyah. PhD thesis, University of Malaya.

Joslee, N. A. (n.d.). Al-Quran Sebagai Penawar-Di dalam Surah Al-Israa' Ayat. Retrieved from Academia.edu: https://www.academia.edu/23726532/AL-QURAN_SEBAGAI_PENAWARDi_dalam_Surah_Al-Israa_Ayat

Kamus, I. (2016). Al-Quran dan Perubatan. Seminar al-Quran 2016.

Mdekmal, C. (2018). Ayat Al-Quran Penyembuh Segala Penyakit. Retrieved from MDekmal: Blog Informasi Dan Panduan: http://mdekmal.com/ayat-al-quran-penyembuh-segalapenyakit/

Mokhtar, W. K. A. W. (2017). Concept Al-Hadīth Al-Mawḍ̂̄'iy as a Method of Collecting and Analyzing Research's Data. International Journal of Academic Research in Business and Social Sciences, 7(2), 2222-6990.

Ramasamy, S. a/p, Rahman, F. A., Manaf, U. K. A., \& Said, R. R. (2018). The Inculcation of Higher Order Thinking Skills in History Subject through the Application of Multiple Intelligence Theory. International Journal of Academic Research in Progressive Education and Development, 7(4), 51-59.

Samail, N. A. B., Zaidi, N. S. B., Mohamed, A. S. B, Kamaruzaman, M. N. B. (2018). Determinants of Financial Performance of Islamic Banking in Malaysia, International Journal of Academic Research in Accounting, Finance and Management Sciences 8 (4): 21-29. 